\title{
Sustained biochemical control in patients with
} acromegaly treated with lanreotide depot $120 \mathrm{mg}$ administered every 4 weeks, or an extended dosing interval of 6 or 8 weeks: a pharmacokinetic
approach

This article was published in the following Dove Press journal:

Research and Reports in Endocrine Disorders

13 December 2012

Number of times this article has been viewed

\author{
Edda Gomez-Panzani' \\ Stephen Chang' \\ Joaquim Ramis ${ }^{2}$ \\ Michelle M Landolfi' \\ Bert Bakker' \\ 'Ipsen Biopharmaceuticals, Inc, Basking \\ Ridge, New Jersey, USA; ${ }^{2}$ psen \\ Innovation SAS, Pharmacokinetic and \\ Drug Metabolism, Les Ulis, France
}

Correspondence: Edda Gomez-Panzani 106 Allen Road, 3rd Floor, Basking Ridge, NJ 07920, USA

Tel + I 6502381627

Fax $+\mathrm{I} 6502435153$

Email edda.gomez-panzani@ipsen.com
Objective: Lanreotide depot is a long-acting somatostatin receptor ligand injected deep subcutaneously every 4 weeks for the treatment of acromegaly. The aim of the presented studies was to establish whether lanreotide depot, administered to patients with acromegaly at an extended dosing interval of 6 or 8 weeks, is effective in maintaining appropriate serum growth hormone (GH) and insulin-like growth factor-1 (IGF-1) levels, with acceptable tolerability.

Methods: Two studies were conducted. Study B1 compared lanreotide depot $120 \mathrm{mg}$ (every 4,6 , or 8 weeks) with lanreotide microparticle formulation $30 \mathrm{mg}$ (every 7, 10, or 14 days) in 98 patients who had a GH level of $\leq 2.5 \mathrm{ng} / \mathrm{mL}$ and normalized IGF-1. Study B2 evaluated lanreotide depot $120 \mathrm{mg}$ administered to 64 patients every 8 weeks, after which the dosing interval was adjusted based on GH levels.

Results: Mean lanreotide trough serum concentrations at steady state for all dosing intervals were $>1.13 \mathrm{ng} / \mathrm{mL}$, shown to achieve a GH level of $\leq 2.5 \mathrm{ng} / \mathrm{mL}$. In Study B1, following treatment with lanreotide depot given every 6 or 8 weeks, $87.5 \%$ and $93.9 \%$ of patients, respectively, had normalized $\mathrm{GH}$, whereas $83.3 \%$ and $88.5 \%$ of patients, respectively, had both normalized GH and IGF-1. In Study B2, 88.9\% had normalized GH and 42.9\% of patients had normalized GH and IGF-1 following lanreotide depot every 8 weeks. Gastrointestinal disorders, generally mild/moderate in severity, were the most common adverse events.

Conclusion: In the studies presented, lanreotide depot $120 \mathrm{mg}$ every 4, 6, or 8 weeks provided effective hormonal control with acceptable safety. An extended dosing interval is a feasible approach for patients adequately controlled with lanreotide depot 60 or $90 \mathrm{mg}$ every 4 weeks.

Keywords: growth hormone, insulin-like growth factor-1, pharmacokinetics, pharmacodynamics

\section{Introduction}

Acromegaly is a chronic condition, characterized by excess secretion of growth hormone $(\mathrm{GH})$ and insulin-like growth factor-1 (IGF-1), typically as a result of a benign pituitary somatotropic adenoma; many of the clinical effects are mediated by elevated levels of IGF-1.1,2 Acromegaly is rare, with an estimated worldwide prevalence of 40-90 cases per million people. . $^{3,4}$

Current treatment options for acromegaly include transsphenoidal surgery as first-line therapy, and medical therapy and radiotherapy (the latter often reserved as either adjuvant therapy for patients who remain uncontrolled after a single surgical 
resection or for postoperative patients who cannot tolerate medical therapy) as second-line therapy. ${ }^{5}$ Medical therapies for acromegaly include somatostatin receptor ligands (SRLs), ${ }^{2}$ the dopamine agonist cabergoline, ${ }^{5}$ and the $\mathrm{GH}$ receptor antagonist pegvisomant. ${ }^{6}$ The decision regarding specific medical therapies is based on the degree of disease activity, comorbidities, and cost. ${ }^{5}$ Long-acting SRLs currently available are lanreotide, most often administered every 4 weeks as a depot formulation (Somatuline ${ }^{\circledR}$ Depot/ Somatuline Autogel ${ }^{\circledR}$, Ipsen Pharma Biotech, Signes, France) and octreotide long-acting release (Sandostatin ${ }^{\circledR}$ LAR, Novartis International, Basel, Switzerland), which requires a deep subcutaneous injection every 4 weeks. Octreotide is also available as a short-acting formulation, usually injected two to three times daily. In some countries, a $30 \mathrm{mg}$ microparticle formulation (MPF) of lanreotide injected every 7, 10, or 14 days is also available.

Based on the findings from three studies in patients with acromegaly (Studies A1, A3, and A4) 7-9 $^{-9}$ and taking the lanreotide serum concentration of $1.13 \mathrm{ng} / \mathrm{mL}$ as the most conservative value needed to reduce serum GH levels to $\leq 2.5 \mathrm{ng} / \mathrm{mL}$, it was hypothesized that, if serum lanreotide levels could be consistently maintained above $1.13 \mathrm{ng} / \mathrm{mL}$ in patients requiring SRLs for the treatment of acromegaly, the dosing interval could be extended beyond 4 weeks without any deleterious effects on GH control. Therefore, two clinical studies were conducted to examine whether lanreotide depot $120 \mathrm{mg}$, administered for an extended dosing interval (EDI) of either 6 or 8 weeks, was effective in maintaining appropriate serum GH levels with an acceptable safety profile. ${ }^{10,11}$ This article describes the pharmacokinetic (PK) profile of lanreotide depot $120 \mathrm{mg}$ in these two clinical studies (B1 and B2).

\section{Materials and methods Lanreotide depot: EDI studies}

\section{Pharmacokinetics}

The first study, B1, compared administration of lanreotide depot 120 mg every 4, 6, and 8 weeks (given as five, five, and three doses, respectively) with lanreotide MPF $30 \mathrm{mg}$, given every $5-7,8-11$, or $12-16$ days in 98 patients previously responsive to treatment with lanreotide MPF. ${ }^{10}$ The design of this study allowed accurate calculation of minimum serum concentration $\left(\mathrm{C}_{\min }\right)$ values, following three or five injections of lanreotide depot $120 \mathrm{mg}$, at 4-, 6-, or 8-week intervals, and an adequate follow-up period after the final dose for each of the dosing schedules. ${ }^{10} \mathrm{GH}$ concentrations were measured with an immunoradiometric assay from Nichols Institute Diagnostics
(San Juan de Capistrano, CA), with a detection limit of $0.02 \mathrm{ng} / \mathrm{mL}$ and intra- and inter-analysis variation coefficients of $5.1 \%$ and $14.9 \%$, respectively. IGF-1 was measured with an immunoradiometric assay from Nichols Institute Diagnostics, with a detection limit of $4.6 \mathrm{ng} / \mathrm{mL}$ and intra- and inter-analysis variation coefficients of $5.9 \% .{ }^{10}$ Mean \pm standard deviation (SD) lanreotide trough serum levels $\left(\mathrm{C}_{\text {min }}\right)$ were reported for each dose interval group at the following times: after the final dose of lanreotide MPF $30 \mathrm{mg}$ prior to treatment with lanreotide depot $120 \mathrm{mg}$, before the final dose of lanreotide depot $120 \mathrm{mg}$, and at the end of the dosing period or at the end of the study.

The second study, B2, was an open-label non-comparative multicenter trial evaluating the efficacy and safety of lanreotide depot $120 \mathrm{mg}$ in 64 SRL-naive patients with active acromegaly (GH $\geq 5 \mathrm{ng} / \mathrm{mL}) .{ }^{11}$ In the initial phase, all patients received three injections of lanreotide depot, one every 8 weeks. Patients were then treated at differing intervals based on their GH levels after this regimen: lanreotide depot $120 \mathrm{mg}$ was administered every 4 weeks (group C) if $\mathrm{GH}$ was $>5 \mathrm{ng} / \mathrm{mL}, 6$ weeks (group B) if $2.5<\mathrm{GH} \leq 5 \mathrm{ng} / \mathrm{mL}$, or 8 weeks (group A) if GH was $\leq 2.5 \mathrm{ng} / \mathrm{mL}$. GH was measured as described for Study B1, with a sensitivity of $0.01 \mu \mathrm{g} / \mathrm{L}$. IGF-1 was measured using immunochemicals and tracers provided by Biosource (Nivelles, Belgium), with an assay sensitivity of $150 \mathrm{pg} / \mathrm{mL} .^{11}$

Steady-state trough serum lanreotide concentrations (minimum serum concentration at steady state $\left[\mathrm{C}_{\min s \mathrm{~s}}\right]$ ) were assessed in patients with quantifiable PK data after the sixth injection (for those in the 4- to 6-week interval groups [B and $\mathrm{C}]$ ) or after the fourth injection (for those in the 8-week interval group [A]). Average $\mathrm{C}_{\text {min ss }}$ was calculated as the mean value from three injections (group A), the mean value from two injections (group B), and the mean value from five injections (group C).

\section{Efficacy}

The efficacy analysis focused on the number and proportion of responding patients; response was defined as achievement of biochemical control (serum $\mathrm{GH} \leq 2.5 \mathrm{ng} / \mathrm{mL}$ with lanreotide depot every 4 weeks and maintenance of that control with lanreotide depot at an EDI of 6 or 8 weeks). An additional analysis was performed to assess the number and proportion of responders who, in addition to achieving biochemical control of serum $\mathrm{GH} \leq 2.5 \mathrm{ng} / \mathrm{mL}$, also had normalized serum IGF-1 (age- and gender-adjusted) levels.

\section{Safety}

Questionnaires, solicited by direct questioning, were used for the collection of adverse event (AE) data in Studies 
$\mathrm{B} 1$ and $\mathrm{B} 2$. AEs related to treatment (an AE starting after the first drug administration) and serious adverse events (SAEs) were pooled from Studies B1 and B2 to define the safety profile of patients treated at an EDI. The most commonly reported AEs (overall incidence $\geq 5 \%$ ) are presented and all AEs and SAEs were recorded.

\section{Results}

\section{Lanreotide depot: EDI studies}

\section{Baseline characteristics}

In Study B1, all patients comprising the intention-to-treat population had been diagnosed with acromegaly a mean ( \pm standard error $[\mathrm{SE}])$ of $9.4( \pm 0.7)$ years before inclusion in the study; their mean $( \pm \mathrm{SE})$ age was $50.8( \pm 1.4)$ years, 42/93 (45.2\%) were male and 51/93 (54.8\%) were female. Previous treatment for acromegaly included adenomectomy in 74/93 (79.6\%) patients and radiotherapy in 50/93 (53.8\%). In Study B2, all patients comprising the intentionto-treat population had been diagnosed with acromegaly for a mean (SD) of 9.8 (27.8) months before inclusion in the study. Their mean (SD) age was 48.0 (14.6) years, 28/63 (44\%) were male and 35/63 (56\%) were female. Previous treatment for acromegaly included surgery in $17 / 61$ $(27.9 \%)$ patients.

\section{Pharmacokinetics}

A total of 93 patients with acromegaly completed Study $\mathrm{B} 1$. The mean $\pm \mathrm{SD}$ lanreotide $\mathrm{C}_{\min \text { ss }}$ for the different treatment groups in Study B1 are shown in Table 1. In Study B2, 64 patients with acromegaly received treatment, of whom 35 provided quantifiable $\mathrm{PK}$ data. The mean $\pm \mathrm{SD}$ and $95 \%$ confidence intervals (CIs) of $\mathrm{C}_{\text {min ss }}$ and average $\mathrm{C}_{\text {min ss }}$ following lanreotide depot $120 \mathrm{mg}$ given every

Table I Summary of mean \pm standard deviation (SD) lanreotide concentrations for the different treatment groups in Study BI

\begin{tabular}{llll}
\hline $\begin{array}{l}\text { Treatment } \\
\text { group }\end{array}$ & \multicolumn{3}{l}{$\begin{array}{l}\text { Mean } \pm \text { SD lanreotide serum } \\
\text { concentration }(\mathrm{ng} / \mathrm{mL})^{\mathrm{a}}\end{array}$} \\
\cline { 2 - 4 } & $\begin{array}{l}\text { Dosed every } \\
\text { 4 weeks; } \\
\text { five doses }\end{array}$ & $\begin{array}{l}\text { Dosed every } \\
\text { 6 weeks; } \\
\text { five doses }\end{array}$ & $\begin{array}{l}\text { Dosed every } \\
\mathbf{8} \text { weeks; } \\
\text { three doses }\end{array}$ \\
\hline $\begin{array}{l}\text { Screening } \\
\text { (baseline) }\end{array}$ & $2.15 \pm 1.04$ & $1.96 \pm 0.90$ & $\mathrm{I} .38 \pm 0.57$ \\
Visit 3 $^{\mathrm{c}}$ & $2.43 \pm 0.58$ & $2.17 \pm 0.75$ & $\mathrm{I} .65 \pm 1.04$ \\
Visit 4 $^{\mathrm{d}}$ & $2.39 \pm 0.68$ & $2.21 \pm 0.77$ & $\mathrm{I} .65 \pm 0.50$ \\
\hline
\end{tabular}

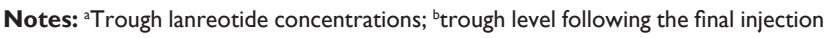
of lanreotide microparticle formulation prior to treatment with lanreotide depot. Patients enrolled in the study had received lanreotide microparticle formulation for $\geq 2$ months to attain steady-state concentrations; 'trough level prior to the final lanreotide depot administration; 'trough level at the end of the dosing period/last visit/end of study.
4, 6, or 8 weeks from Study B2 are shown in Table 2. No significant differences were noted between $\mathrm{C}_{\text {minss }}$ and average $\mathrm{C}_{\text {minss }}$ for any groups. Following dosing with lanreotide depot $120 \mathrm{mg}$ (every 6 or 8 weeks), the mean lanreotide trough serum concentration at steady state was $>1.13 \mathrm{ng} / \mathrm{mL}$, the level required to decrease the $\mathrm{GH}$ level to $\leq 2.5 \mathrm{ng} / \mathrm{mL}$ (Figure 1).

\section{Efficacy}

In Study B1, the proportion of patients who, after receiving lanreotide depot $120 \mathrm{mg}$ (every 6 or 8 weeks), had a GH level of $\leq 2.5 \mathrm{ng} / \mathrm{mL}$ and IGF-1 concentrations normalized is shown in Table 3 . A total of $7 / 8(87.5 \%)$ of patients who switched to lanreotide depot $120 \mathrm{mg}$ every 6 weeks and $31 / 33$ (93.9\%) of patients who switched to lanreotide depot $120 \mathrm{mg}$ every 8 weeks maintained a GH level of $\leq 2.5 \mathrm{ng} / \mathrm{mL}$ after five and three injections, respectively (Table 3 ). Furthermore, 5/6 (83.3\%) of patients who switched to lanreotide depot $120 \mathrm{mg}$ every 6 weeks and 23/26 (88.5\%) of patients who switched to lanreotide depot $120 \mathrm{mg}$ every 8 weeks maintained a $\mathrm{GH}$ level of $\leq 2.5 \mathrm{ng} / \mathrm{mL}$ and normalized IGF-1 levels after five and three injections, respectively (Table 3 ).

In Study B2, following lanreotide depot $120 \mathrm{mg}$ every 8 weeks, $16 / 18(88.9 \%)$ of patients maintained a $\mathrm{GH}$ level of $\leq 2.5 \mathrm{ng} / \mathrm{mL}$ and $3 / 7(42.9 \%)$ maintained a $\mathrm{GH}$ level of $\leq 2.5 \mathrm{ng} / \mathrm{mL}$ and normalized IGF-1 levels at the final visit after two injections. None of the 16 patients in the lanreotide depot $120 \mathrm{mg}$ every 6 weeks group had a $\mathrm{GH}$ level of $\leq 2.5 \mathrm{ng} / \mathrm{mL}$ prior to the EDI treatment (Table 3).

Table 2 Minimum serum concentration at steady state $\left(C_{\text {minss }}\right)$ values after lanreotide depot $120 \mathrm{mg}$ injections administered every 4, 6, and 8 weeks in Study B2

\begin{tabular}{llll}
\hline Group & Parameter & $\begin{array}{l}\mathbf{C}_{\text {min ss }} \mathbf{a} \\
(\mathbf{n g} / \mathbf{m L})\end{array}$ & $\begin{array}{l}\text { Average } \mathbf{C}_{\text {min ss }}{ }^{\mathrm{b}} \\
(\mathbf{n g} / \mathbf{m L})\end{array}$ \\
\hline A: I20 mg every & Mean $\pm \mathrm{SD}$ & $1.62 \pm 0.53$ & $\mathrm{I} .61 \pm 0.59$ \\
8 weeks & $\mathrm{n}$ & 13 & 10 \\
& $95 \% \mathrm{Cl}$ & $(1.22,2.02)$ & $(1.19,2.04)$ \\
B: $120 \mathrm{mg}$ every & Mean $\pm \mathrm{SD}$ & $2.30 \pm 0.45$ & $2.23 \pm 0.44$ \\
6 weeks & $\mathrm{n}$ & 8 & 7 \\
& $95 \% \mathrm{Cl}$ & $(1.79,2.8 \mathrm{I})$ & $(1.72,2.74)$ \\
C: $120 \mathrm{mg}$ every & Mean $\pm \mathrm{SD}$ & $3.07 \pm 0.97$ & $3.36 \pm 0.79$ \\
4 weeks & $\mathrm{n}$ & 14 & $1 \mathrm{I}$ \\
& $95 \% \mathrm{Cl}$ & $(2.68,3.45)$ & $(2.95,3.76)$ \\
\hline
\end{tabular}

Notes: aSteady-state serum concentrations were assumed after the fourth injection (visit 5) from the start of the study for group A, and after the sixth injection (visit 7) from the start of the study for groups $B$ and $C$; ${ }^{b}$ calculated as the mean value of visits 5, 6, and 7 (group A), visits 7 and 8 (group B), and visits 7, 8, 9, 10, and II (group C).

Abbreviations: $\mathrm{Cl}$, confidence interval; SD, standard deviation. 


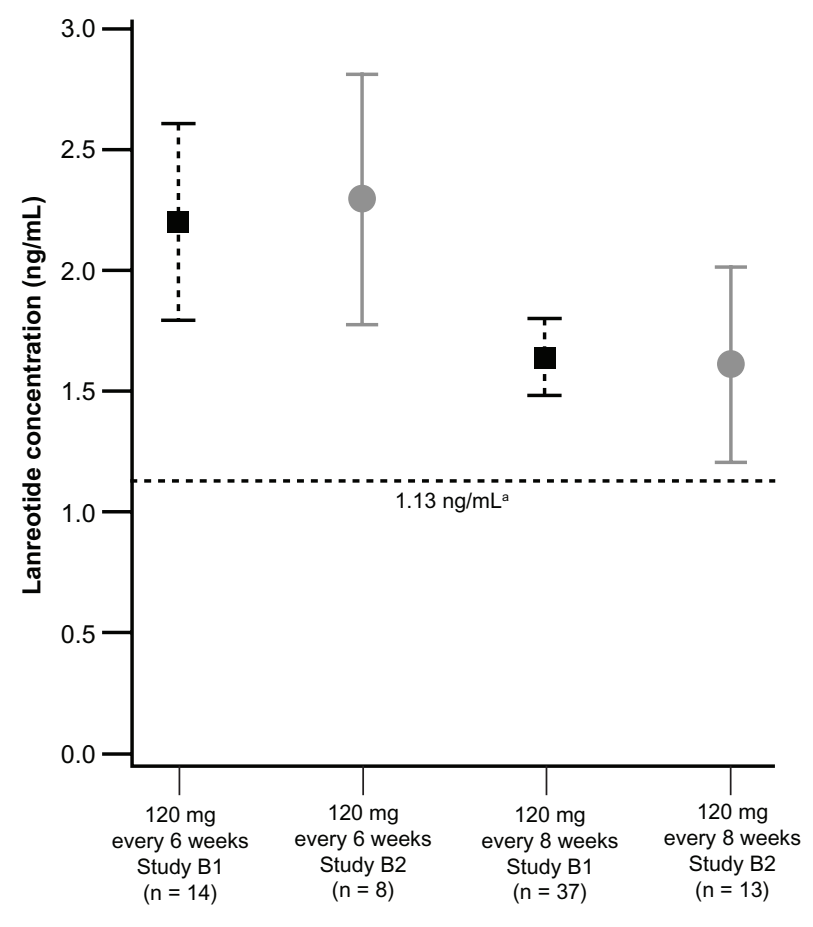

Figure I Mean ( $95 \%$ confidence interval) lanreotide serum concentrations at steady state following administration of lanreotide depot $120 \mathrm{mg}$ every 6 or 8 weeks. Note: ${ }^{2}$ The lanreotide serum level needed to decrease the growth hormone level to $\leq 2.5 \mathrm{ng} / \mathrm{mL}$.

\section{Safety}

The incidence of commonly reported AEs ( $\geq 5 \%$ of patients) in patients with acromegaly, pooled from Studies B1 and B2, was $81.6 \%, 78.7 \%$, and $80.0 \%$ in the $4-, 6$-, and 8 -weekly dosing interval groups, respectively. Diarrhea was the most frequent $\mathrm{AE}$ ( $\geq 5 \%$ of patients), reported in $68.4 \%, 59.6 \%$, and $57.3 \%$ of patients receiving lanreotide depot $120 \mathrm{mg}$ every 4,6 , and 8 weeks, respectively and, in general, the most common AEs were gastrointestinal in nature. Overall, AEs were generally mild or moderate in severity; the incidence of severe AEs was $31.6 \%, 21.3 \%$, and $17.3 \%$, respectively, in the 4-, 6-, and 8- weekly dosing interval groups. The proportions of patients receiving lanreotide depot $120 \mathrm{mg}$ with $\geq 1 \mathrm{AE}$ leading to withdrawal were $2.6 \%$, $6.4 \%$, and $1.3 \%$ in the $4-, 6$-, and 8 -weekly dosing interval groups, respectively. The overall incidence of SAEs pooled from Studies B1 and B2 was 4.4\%; this represented 2.6\%, $4.3 \%$, and $5.3 \%$ in the 4-, 6-, and 8- weekly dosing interval groups, respectively. SAEs reported in Studies B1 and B2 were hip arthroplasty, oophorectomy, and thyroidectomy; none of these SAEs was considered related to treatment. Other SAEs reported in Studies B1 and B2 were atrial fibrillation, increased cortisol-free urine, carpal tunnel syndrome, and ovarian mass. Two patients experienced SAEs (diarrhea and hepatitis) that were considered related to treatment with lanreotide depot $120 \mathrm{mg}$; these patients withdrew from the study.

\section{Discussion}

Untreated patients with acromegaly are faced with many comorbidities and high rates of mortality, with cardiovascular disease accounting for $60 \%$ of all deaths. ${ }^{12-16}$ As a result of these comorbidities, patients with acromegaly are often managed by long-term treatment with agents such as lanreotide depot to suppress GH secretion. Regrettably, treatments of long duration are generally associated with poor compliance. ${ }^{17}$ Patient misperceptions about the lack of consequences of missed doses, uncomfortable injections, inadequate results with the ongoing treatment, and poor levels of contact with health

Table 3 Proportion of patients receiving lanreotide depot at the extended dosing regimen that achieved $\mathrm{GH}$ levels of $\leq 2.5 \mathrm{ng} / \mathrm{mL}$ and normalized IGF-I

\begin{tabular}{|c|c|c|c|c|c|c|c|c|}
\hline \multirow[t]{2}{*}{ Regimen } & \multicolumn{2}{|c|}{$\begin{array}{l}\text { GH } \leq 2.5 \mathrm{ng} / \mathrm{mL} \\
\text { (end of study) } \\
\text { (Study } \mathrm{BI} \text { ) }\end{array}$} & \multicolumn{2}{|c|}{$\begin{array}{l}\text { GH } \leq 2.5 \mathrm{ng} / \mathrm{mL} \\
\text { (end of study) } \\
\text { (Study B2) }\end{array}$} & \multicolumn{2}{|c|}{$\begin{array}{l}\text { GH } \leq 2.5 \mathrm{ng} / \mathrm{mL} \text { and } \\
\text { normalized IGF-I } \\
\text { (end of study) } \\
\text { (Study } \mathrm{BI} \text { ) }\end{array}$} & \multicolumn{2}{|c|}{$\begin{array}{l}\text { GH } \leq 2.5 \mathrm{ng} / \mathrm{mL} \text { and } \\
\text { normalized IGF-I } \\
\text { (end of study) } \\
\text { (Study B2) }\end{array}$} \\
\hline & Yes & No & Yes & No & Yes & No & Yes & No \\
\hline \multicolumn{9}{|c|}{ 6-weekly (baseline) } \\
\hline Yes & $7(87.5)$ & $4(2 I . I)$ & $N / A^{b}$ & $9(56.3)$ & $5(83.3)$ & I (4.8) & $\mathrm{N} / \mathrm{A}^{\mathrm{b}}$ & $2(12.5)$ \\
\hline No & I (I2.5) & I5 (78.9) & $N / A^{b}$ & $7(43.7)$ & I (I6.7) & $20(95.2)$ & $N / A^{b}$ & I4 (87.5) \\
\hline \multicolumn{9}{|c|}{ 8-weekly (baseline) } \\
\hline Yes & $31(93.9)$ & $6(30.0)$ & $16(88.9)$ & $0(0.0)$ & $23(88.5)$ & $6(22.2)$ & $3(42.9)$ & $3(27.3)$ \\
\hline No & $2(6.1)$ & $14(70.0)$ & $2(I I . I)$ & $0(0.0)$ & $3(11.5)$ & $2 \mathrm{I}(77.8)$ & $4(57.1)$ & $8(72.7)$ \\
\hline \multicolumn{9}{|c|}{ Both EDI (baseline) } \\
\hline Yes & $38(92.7)$ & $10(25.6)$ & $16(88.9)$ & $9(56.3)$ & $28(87.5)$ & $7(14.6)$ & $3(42.9)$ & $5(18.5)$ \\
\hline No & $3(7.3)$ & $29(74.4)$ & $2(11.1)$ & $7(43.7)$ & $4(12.5)$ & $4 \mathrm{I}(85.4)$ & $4(57.1)$ & $22(8 \mid .5)$ \\
\hline
\end{tabular}

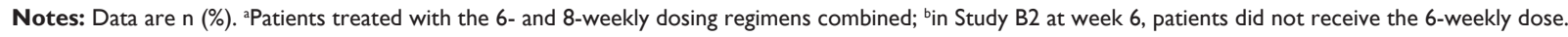
Abbreviations: EDI, extended dosing interval; GH, growth hormone; IGF-I, insulin-like growth factor I. 
care providers are major contributors to non-compliance, as well as external factors like cost of treatment. ${ }^{18}$ Approaches such as reducing the number of injections of long-acting SRLs that a patient needs (by extending the dosing interval), while maintaining consistent plasma levels required to sustain the same biochemical and clinical control could result in an advantage in terms of reducing treatment burden, as well as potentially improving both patient compliance and convenience, and reducing the cost of treatment. ${ }^{10}$ The PK profile and the $\mathrm{PK}$-pharmacodynamic relationship of lanreotide depot have been characterized in a series of four key clinical trials: three in patients with acromegaly ${ }^{7-9}$ and one in healthy subjects. ${ }^{7}$ The first of the trials in patients with acromegaly was a multicenter randomized study in SRL-naive patients with acromegaly (Study A1); the clinical results of this study were published by Melmed et al. ${ }^{7}$ PK analysis of lanreotide serum samples from patients responding to lanreotide depot in this study showed that the median effective serum concentration required to reduce serum $\mathrm{GH}$ levels to $\leq 2.5 \mathrm{ng} / \mathrm{mL}$ (widely accepted as the minimum threshold for GH levels needed for adequate control of acromegaly) ${ }^{19,20}$ was $0.95 \mathrm{ng} / \mathrm{mL}$. Mean $\mathrm{C}_{\text {min ss }}$ following dosing with lanreotide depot 60, 90, and $120 \mathrm{mg}$ ranged from $2.27-3.99 \mathrm{ng} / \mathrm{mL}$; this is more than twofold greater than the serum lanreotide concentration of $0.95 \mathrm{ng} / \mathrm{mL}$ required for adequate control of acromegaly. ${ }^{21}$ The second study (Study A2) was a single-center open-label randomized parallel-group study in healthy subjects. Study A2 established dose linearity with respect to area under the curve, but not maximum serum concentration, which showed high inter-subject variability. Absolute bioavailability ranged from $69.0 \%$ to $78.4 \%$ (lanreotide depot $60-120 \mathrm{mg}$ ). Mean maximum serum concentration ranged from 4.25 to $8.39 \mathrm{ng} / \mathrm{mL}$ and lanreotide depot had an apparent half-life associated with the terminal phase of 23-30 days. Based on the experimental data of this study, a PK population model has been developed. ${ }^{22}$

Lastly, a multicenter open-label study was conducted in patients pre-treated with five injections of lanreotide MPF $30 \mathrm{mg}$ (one every 7-14 days) (Study A3). ${ }^{8}$ Patients were then switched to three fixed doses of lanreotide depot 60,90 , or $120 \mathrm{mg}$ (one every 7-14 days), followed by the extension phase of this study, in which patients received lanreotide depot every 4 weeks up to a maximum of 12 doses. The doses were titrated according to hormonal response (Study A4). ${ }^{9}$ These studies compared the lanreotide depot formulation with the lanreotide MPF and demonstrated that the median lanreotide serum concentration necessary to reduce serum GH levels to $\leq 2.5 \mathrm{ng} / \mathrm{mL}$ was $1.13 \mathrm{ng} / \mathrm{mL} ;{ }^{23}$ this was consistent with although slightly higher than - the value obtained in Study A1.
The mean $\mathrm{C}_{\text {min ss }}$ in Studies A3 and A4 were above this level, and ranged from 1.95 to $3.58 \mathrm{ng} / \mathrm{mL}^{23}$

The data from Study B1 show that biochemical and clinical control was attained in $83 \%$ and $89 \%$ of patients with acromegaly with lanreotide depot given every 6 or 8 weeks, respectively. The data from Study B2 presented here demonstrate that, with fewer injections, biochemical and clinical control equivalent to that reached with dosing every 4 weeks can be achieved in $43 \%$ patients who attain control on doses of 60 or $90 \mathrm{mg}$ of lanreotide depot every 4 weeks. ${ }^{10}$ The PK characteristics of lanreotide depot reported here in Studies B1 and B2 provide support for extending the currently approved dosing interval for some patients who are controlled on lanreotide depot 60 or $90 \mathrm{mg}$ every 4 weeks to an EDI of $120 \mathrm{mg}$ every 6 or 8 weeks. This is based on lanreotide $\mathrm{C}_{\min }$ maintained above the minimum lanreotide concentration of $1.13 \mathrm{ng} / \mathrm{mL}$ required to achieve a $\mathrm{GH}$ level of $\leq 2.5 \mathrm{ng} / \mathrm{mL}$, and this biochemical control being maintained for up to 8 weeks. In addition, the frequency of AEs was generally similar in patients treated with lanreotide depot whether given every 4,6 , or 8 weeks. Consistent with previous studies on lanreotide depot, diarrhea, abdominal pain, and nausea were the most frequently reported gastrointestinal events, and were generally transient.

Another recent study evaluated the efficacy of different dosing intervals of lanreotide depot $120 \mathrm{mg}$ in 35 patients with acromegaly previously treated with octreotide LAR and switched to lanreotide depot (every 4,6 , or 8 weeks). ${ }^{24}$ Overall, $60 \%$ of patients were controlled (normalized IGF-1) at baseline; this was similar to the overall proportion of patients well controlled at the end of the study $(62.9 \%)$. This study showed that almost $50 \%$ of patients in this study could benefit from an EDI of 6 or 8 weeks with lanreotide depot; ${ }^{24}$ these findings are consistent with the results of the EDI studies presented here. Patient preference for lanreotide depot was higher in the 8-weekly dosing interval groups (71\%) compared with 54\% and 41\% in the 6- and 4-weekly dosing interval groups, respectively. ${ }^{24}$

\section{Conclusion}

The results of the studies presented here demonstrate that lanreotide depot $120 \mathrm{mg}$ administered every 4,6 , or 8 weeks can provide effective GH and IGF-1 control, with a safety profile similar to that seen with the traditional 4-week dosing interval. Being able to extend the dosing interval of lanreotide depot from 60 or $90 \mathrm{mg}$ every 4 weeks to $120 \mathrm{mg}$ every 6 or 8 weeks could provide a desirable alternative for the treatment of certain patients with acromegaly. Consistent with previous studies 
on lanreotide, a proportion of patients do not respond to SRL treatment; such patients may benefit from supplementing SRL treatment with a GH antagonist such as pegvisomant. ${ }^{25,26}$

\section{Acknowledgments}

The authors accept direct responsibility for this paper and are grateful for the contribution made by Watermeadow Medical, supported by Ipsen Biopharmaceuticals, Inc, in developing the first draft from an agreed outline and in collating comments.

\section{Disclosures}

Edda Gomez-Panzani is currently a full-time employee of Ipsen Biopharmaceuticals, Inc. Stephen Chang, Michelle Landolfi, and Bert Bakker were full-time employees of Ipsen Biopharmaceuticals, Inc, at the time of manuscript preparation. Joaquim Ramis was a full-time employee for Ipsen Biopharmaceuticals, Inc, at the time of manuscript preparation and is currently a consultant for Ipsen Innovation SAS. The authors declare no other conflicts of interest in this work.

\section{References}

1. Clemmons DR. Role of insulin-like growth factor-I in diagnosis and management of acromegaly. Endocr Pract. 2004;10(4):362-371.

2. Melmed S. Medical progress: acromegaly. NEngl J Med. 2006;355(24): 2558-2573.

3. Colao A, Ferone D, Marzullo P, Lombardi G. Systemic complications of acromegaly: epidemiology, pathogenesis, and management. Endocr Rev. 2004;25(1):102-152.

4. Chanson P, Salenave S, Kamenicky P, Cazabat L, Young J. Pituitary tumours: acromegaly. Best Pract Res Clin Endocrinol Metab. 2009;23(5): 555-574.

5. Melmed S, Colao A, Barkan A, et al; Acromegaly Consensus Group. Guidelines for acromegaly management: an update. J Clin Endocrinol Metab. 2009;94(5):1509-1517.

6. Neggers SJ, van der Lely AJ. Combination treatment with somatostatin analogues and pegvisomant in acromegaly. Growth Horm IGF Res. 2011;21(3):129-133.

7. Melmed S, Cook D, Schopohl J, Goth MI, Lam KS, Marek J. Rapid and sustained reduction of serum growth hormone and insulin-like growth factor-1 in patients with acromegaly receiving lanreotide Autogel therapy: a randomized, placebo-controlled, multicenter study with a 52 week open extension. Pituitary. 2010;13(1):18-28.

8. Caron P, Beckers A, Cullen DR, et al. Efficacy of the new long-acting formulation of lanreotide (lanreotide Autogel) in the management of acromegaly. J Clin Endocrinol Metab. 2002;87(1):99-104.

9. Caron P, Bex M, Cullen DR, et al; Group for Lanreotide Autogel Long-Term Study on Acromegaly. One-year follow-up of patients with acromegaly treated with fixed or titrated doses of lanreotide Autogel. Clin Endocrinol (Oxf). 2004;60(6):734-740.

Research and Reports in Endocrine Disorders

\section{Publish your work in this journal}

Research and Reports in Endocrine Disorders is an international, peerreviewed, open access journal publishing original research, reports, reviews and commentaries on all areas of endocrinology, endocrine
disorders and therapeutic interventions. The manuscript managedisorders and therapeutic interventions. The manuscript manage-
ment system is completely online and includes a very quick and fair
10. Lucas T, Astorga R; Spanish-Portuguese Multicentre Autogel Study Group on Acromegaly. Efficacy of lanreotide Autogel administered every $4-8$ weeks in patients with acromegaly previously responsive to lanreotide microparticles $30 \mathrm{mg}$ : a phase III trial. Clin Endocrinol (Oxf). 2006;65(3):320-326.

11. Lombardi G, Minuto F, Tamburrano G, et al. Efficacy of the new long-acting formulation of lanreotide (lanreotide Autogel) in somatostatin analogue-naive patients with acromegaly. $J$ Endocrinol Invest. 2009;32(3):202-209.

12. Wright AD, Hill DM, Lowy C, Fraser TR. Mortality in acromegaly. Q J Med. 1970;39(153):1-16.

13. Bates AS, Van't Hoff W, Jones JM, Clayton RN. An audit of outcome of treatment in acromegaly. Q J Med. 1993;86(5):293-299.

14. Etxabe J, Gaztambide S, Latorre P, Vazquez JA. Acromegaly: an epidemiological study. J Endocrinol Invest. 1993;16(3):181-187.

15. Rajasoorya C, Holdaway IM, Wrightson P, Scott DJ, Ibbertson HK. Determinants of clinical outcome and survival in acromegaly. Clin Endocrinol (Oxf). 1994;41(1):95-102.

16. Abosch A, Tyrrell JB, Lamborn KR, Hannegan LT, Applebury CB, Wilson CB. Transsphenoidal microsurgery for growth hormone-secreting pituitary adenomas: initial outcome and long-term results. $J$ Clin Endocrinol Metab. 1998;83(10):3411-3418.

17. Fuh G, Cunningham BC, Fukunaga R, Nagata S, Goeddel DV, Wells JA. Rational design of potent antagonists to the human growth hormone receptor. Science. 1992;256(5064):1677-1680.

18. Rosenfeld RG, Bakker B. Compliance and persistence in pediatric and adult patients receiving growth hormone therapy. Endocr Pract. 2008;14(2):143-154.

19. Kauppinen-Mäkelin R, Sane T, Reunanen A, et al. A nationwide survey of mortality in acromegaly. J Clin Endocrinol Metab. 2005;90(7): 4081-4086.

20. Holdaway IM, Rajasoorya RC, Gamble GD. Factors influencing mortality in acromegaly. J Clin Endocrinol Metab. 2004;89(2):667-674.

21. Ramis J, Cendros JM, Catus F, Schopohl JS. Pharmacokinetics and pharmacodynamics of lanreotide Autoge $\mathrm{l}^{\circledR}$ after multiple subcutaneous administration in patients with acromegaly: a 52-week, multi-centre, randomized study. Poster presented at the 12th International Congress of Endocrinology, August 31-September 4, 2004, Lisbon, Portugal.

22. Trocóniz IF, Cendrós JM, Peraire C, et al. Population pharmacokinetic analysis of lanreotide Autogel in healthy subjects: evidence for injection interval of up to 2 months. Clin Pharmacokinet. 2009;48(1):51-62.

23. Cendros JM, Peraire C, Trocóniz IF, Obach R. Pharmacokinetics and population pharmacodynamic analysis of lanreotide Autogel. Metabolism. 2005;54(10):1276-1281.

24. Schopohl J, Strasburger CJ, Caird D, et al; German Lanreotide Study Group. Efficacy and acceptability of lanreotide Autogel ${ }^{\circledR} 120 \mathrm{mg}$ at different dose intervals in patients with acromegaly previously treated with octreotide LAR. Exp Clin Endocrinol Diabetes. 2011; 119(3):156-162.

25. Feenstra J, de Herder WW, ten Have SM, et al. Combined therapy with somatostatin analogues and weekly pegvisomant in active acromegaly. Lancet. 2005;365(9471):1644-1646.

26. Marzullo P, Ferone D, Di Somma C, et al. Efficacy of combined treatment with lanreotide and cabergoline in selected therapy-resistant acromegalic patients. Pituitary. 1999;1(2):115-120.

\section{Dovepress}

peer-review system. Visit http://www.dovepress.com/testimonials.php to read real quotes from published authors. 